\title{
Bukholderia strains promote Mimosa spp. growth but not Macroptilium atropurpureum ${ }^{1}$
}

\author{
Estirpes de Burkholderia promovem o crescimento de Mimosa spp. mas não o de \\ Macroptilium atropurpureum
}

\author{
Kaliane Sírio Araújo² ${ }^{2}$ Fernanda de Carvalho ${ }^{3}$ and Fatima Maria de Souza Moreira ${ }^{4 *}$
}

\begin{abstract}
The aim of this study was to evaluate the relationship and symbiotic efficiency of 14 strains of Burkholderia isolated from rupestrian grasslands, using M. atropurpureum and Mimosa tenuiflora as trap plants, with the species $M$. atropurpureum, Mimosa bimucronata and M. foliolosa. For the nodulation and symbiotic efficiency test in M. atropurpureum, long-neck bottles containing nutrient solution were used. The experiments with Mimosa spp. were carried out in tubes containing vermiculite $\left(160 \mathrm{~cm}^{3}\right)$ and sand $\left(80 \mathrm{~cm}^{3}\right)(2: 1)$. The parameters under evaluation were number of nodules, nodules dry matter production, shoots dry matter, roots dry matter, and total dry matter production for all the species analyzed; and plant height, diameter, and the Dickson quality index for Mimosa species. Of the 14 tested strains, two nodulated $M$. atropurpureum; however, they were ineffective in promoting plant growth. All the tested strains established symbiosis with $M$. bimucronata, and 12 strains nodulated $M$. foliolosa. Of these, six promoted growth in $M$. bimucronata, and seven presented symbiotic efficiency in $M$. foliolosa. The strains UFLA 01-739, UFLA 01-748 and UFLA 01-751, isolated from M. tenuiflora, and UFLA 04-260 and UFLA 04-405, isolated from M. atropurpureum, stood out as potential inoculants for the Mimosa species evaluated in this study.
\end{abstract}

Key words: Rupestrian grasslands. Nitrogen-fixing bacteria. Symbiosis. Mimosa bimucronata. Mimosa foliolosa.

\begin{abstract}
RESUMO - O objetivo deste trabalho foi avaliar a relação e a eficiência simbiótica de 14 estirpes de Burkholderia isoladas de campos rupestres, utilizando M. atropurpureum e Mimosa tenuiflora como plantas iscas, com as espécies: M. atropurpureum, Mimosa bimucronata e $M$. foliolosa. Para o teste de nodulação e eficiência simbiótica em M. atropurpureum foram utilizadas garrafas do tipo long neck, contendo solução nutritiva. Os experimentos com as Mimosa spp. foram realizados em tubetes contendo vermiculita $\left(160 \mathrm{~cm}^{3}\right)$ e areia $\left(80 \mathrm{~cm}^{3}\right)(2: 1)$. Os parâmetros avaliados foram número de nódulos, produções de massa de matéria seca de nódulos, da parte aérea, da raiz e total para todas as espécies vegetais analisadas, e altura da planta, diâmetro, e o índice de qualidade de Dickson para as espécies de Mimosa. Das 14 estirpes avaliadas, duas foram capazes de nodular M. atropurpureum. Entretanto, estas foram ineficientes na promoção de crescimento vegetal. Todas as estirpes testadas estabeleceram simbiose com M. bimucronata e 12 estirpes nodularam M. foliolosa. Destas, seis promoveram o crescimento de M. bimucronata e sete apresentaram eficiência simbiótica em $M$. foliolosa. Destacam-se as estirpes UFLA 01-739, UFLA 01748, UFLA 01-751 isoladas de M. tenuiflora e UFLA 04-260 e UFLA 04-405 isoladas de M. atropurpureum como potenciais inoculantes para as espécies de Mimosa avaliadas.
\end{abstract}

Palavras-chave: Campos rupestres. Bactérias fixadoras de nitrogênio. Simbioses. Mimosa bimucronata. Mimosa foliolosa.

\footnotetext{
DOI: $10.5935 / 1806-6690.20170005$

*Autor para correspondência

${ }^{1}$ Recebido para publicação em 25/11/2015; aprovado em 20/05/2016

Dados extraídos parcialmente da Dissertação de Mestrado da primeira autora

${ }^{2}$ Departamento de Biologia, Universidade Federal de Lavras/UFLA, Av. Central, s/n - Campus Universitário, Lavras-MG, 37.200-000, kalianesirio@ hotmail.com

${ }^{3}$ Bolsista de Pós Doutorado, Universidade Federal de Lavras/UFLA, fernandacarva@ hotmail.com

${ }^{4}$ Departamento de Ciência do Solo, Universidade Federal de Lavras/UFLA, Caixa Postal 3037, Lavras-MG, 37.200-000, fmoreira@dcs.ufla.br
} 


\section{INTRODUCTION}

Bacteria of the Burkholderia genus occupy a variety of ecological niches, and are exploited for several purposes, such as biological control, bioremediation, and plant growth promotion (COENYE; VANDAMME, 2003). The first Burkholderia strains with nodulation capacity were proven in Macroptilium atropurpureum (DC), which were isolated from nodules of Aspalathus carnosa Bergius and Machaerium lunatum (L. f.) Ducke (MOULIN et al., 2001).

Since then, it has been proven the ability of Burkholderia species to nodulate $M$. atropurpureum (ANGUS et al., 2013; ELLIOT et al., 2007; LIMA et al., 2009), Cyclopia spp. (ELLIOT et al., 2007), Vigna unguiculata (L.) Walp (SOARES et al., 2014), Phaseolus vulgaris L. (FERREIRA et al., 2012; TALBI et al., 2010), and Mimosa spp. (BARRET; PARKER, 2005; BONTEMPS et al., 2010; CHEN et al., 2003, 2005, 2006; REIS JÚNIOR et al., 2010).

Although it has been proven the nodulation of M. atropurpureum and Mimosa spp. by Burkholderia strains, the symbiotic effectiveness of these relationships is still unknown. The efficiency of these strains has been mainly reported by means of observations by the nodules internal color, and it was verified the presence or absence of leghemoglobin. Moulin et al. (2001) and Barrett and Parker (2005) verified that nodules formed in $M$. atropurpureum were ineffective due to the whitish color, and did not observe the presence of leghemoglobin. Chen et al. (2005) suggested that the strains of Burkholderia $\mathrm{Br} 3407, \mathrm{Br} 3454, \mathrm{Br} 3461, \mathrm{Br} 3469$ and MAP3-5 were efficient in Mimosa pudica L., M. diplotricha C. Wright ex Sauvalle, M. pigra L. and M. acutispula Benth. due to the internal reddish color of the nodule. In addition to nodules internal color, some authors report the efficiency and/or inefficiency of Burkholderia strains by means of the evaluation of nitrogenase activity in Mimosa spp. nodules. (CHEN et al., 2005; ELLIOTT et al., 2007; REIS JÚNIOR et al., 2010), and few studies have evaluated the development of the plants inoculated with Burkholderia strains. It was observed the efficiency of Burkholderia phymatum (STM815 ${ }^{\mathrm{T}}$ ) to promote the growth of Mimosa pudica (ELLIOTT et al., 2007), but the same was not observed when this species was inoculated with Burkholderia Hpud10.4(C) (BARRETT; PARKER, 2006). On the other hand, in M. atropurpureum, it was verified greater dry matter production and shoot length of plant when it was inoculated with Burkholderia tuberum $\left(\mathrm{STM} 678^{\mathrm{T}}\right)$. However, this increase was attributed to other processes rather than biological nitrogen fixation, since the observed nodules were ineffective (ANGUS et al., 2013).
Considering the economic and ecological importance of M. atropurpureum and Mimosa spp., as well as the biotechnological potential of Burkholderia strains, this study aimed to verify the relationship and symbiotic efficiency of Burkholderia strains isolated from nodules of $M$. atropurpureum and Mimosa tenuiflora (Willd.) Poir. cultivated in rupestrian grasslands soils in M. atropurpureum, Mimosa bimucronata (DC.) Kuntze and Mimosa foliolosa Benth. subsp. pachycarpa (Benth.) Barneby var. pachycarpa.

\section{MATERIAL AND METHODS}

The 14 Burkholderia sp. strains evaluated regarding their relationship and symbiotic efficiency in Macropitilium atropurpureum, Mimosa bimucronata and $M$. foliolosa were isolated from nodules of $M$. atropurpureum and $M$. tenuiflora grown in distinct soils of rupestrian grasslands, located in Serra do Cipó, Minas Gerais, Brazil (CARVALHO, 2010). Table 1 shows the cultural characteristics and origin of these strains. The 14 strains were deposited in the GenBank under the accession number KT957898 to KT957912.

Three experiments were carried out in a greenhouse. Each experiment consisted of 17 treatments: 14 treatments corresponded to the inoculation of each Burkholderia strain in nutrient solution (HOAGLAND; ARNON, 1950), containing low mineral N concentration (5.25 mg L $\left.\mathrm{m}^{-1}\right)$; two uninoculated negative controls, one with low mineral $\mathrm{N}$ concentration $\left(5.25 \mathrm{mg} \mathrm{L}^{-1}\right)$, and another with high mineral $\mathrm{N}$ concentration $\left(52.5 \mathrm{mg} \mathrm{L}^{-1}\right)$; and one positive control in nutrient solution with low mineral $\mathrm{N}$ concentration $\left(5.25 \mathrm{mg} \mathrm{L}^{-1}\right)$, inoculated with a nodulating strain, according to the host plant species UFLA 04-212 - Bradyrhizobium sp, for M. atropurpureum (FLORENTINO et al., 2009), BR3460 - Burkholderia gladioli for M. bimucronata (FARIA et al., 1997) and UFLA 01-750 - Burkholderia sp. for $M$. foliolosa. The mineral $\mathrm{N}$ sources used were $\mathrm{Ca}\left(\mathrm{NO}_{3}\right)_{2} \cdot 4 \mathrm{H}_{2} \mathrm{O} ; \mathrm{KNO}_{3}$ and $\mathrm{NH}_{4} \mathrm{H}_{2} \mathrm{PO}_{4}$.

Each treatment in the experiment with $M$. atropurpureum consisted of three replications. For the experiment with $M$. bimucronata and $M$. foliolosa, each treatment consisted of eight replications.

The experiment with $M$. atropurpureum was carried out from September $17^{\text {th }} 2013$ to October $28^{\text {th }}$ 2013, and temperature ranged between 16 to $27^{\circ} \mathrm{C}$. Long neck bottles containing nutrient solution (HOAGLAND; ARNON, 1950) were used in the experiment. The bottles were autoclaved for one hour, at $1.5 \mathrm{~kg} \mathrm{~cm}^{-2}$ pressure and $127{ }^{\circ} \mathrm{C}$. M. atropurpureum seeds were surface sterilized 
using 98\% ethyl alcohol (30 seconds), 2\% sodium hypochlorite ( 2 minutes), and then scarified with pure sulfuric acid (20 minutes). After this period, seeds were subjected to successive washes in sterile distilled water. Afterwards, seeds were placed in petri dishes containing sterilized filter paper and moistened cotton, where they remained for 48 hours in a growth chamber, at $28^{\circ} \mathrm{C}$, for the pre-sprouting seed. One plantlet per bottle was used. The 17 strains were grown in liquid culture medium "79" (FRED; WAKSMAN, 1928) for 3 days for Burkholderia strains, and for 5 days for UFLA 04-212 (Bradyrhizobium sp.), due to differences in the growth time of the strains under shaking $(110 \mathrm{rpm})$, at $28{ }^{\circ} \mathrm{C}$. In each inoculated treatment, plantlets were microbiolyzed with $2 \mathrm{ml}$ inoculum in minimum concentration of $1 \times 10^{8}$ bacterial cells $\mathrm{mL}^{-1}$. At 40 days, plants were collected to determine number of nodules $(\mathrm{NN})$, shoot dry matter production (SDM), root dry matter (RDM), and total dry matter (TDM), and the result was obtained by the sum of SDM and RDM. Data were subjected to analysis of variance, by using the statistical analysis program SISVAR, version 5.3 (FERREIRA, 2011). The effects of the treatments were compared by the Scott-Knott test at 5\% probability.

Experiments in M. bimucronata and M. foliolosa were carried out, respectively, from July $22^{\text {nd }}$ to October $2^{\text {nd }}, 2013$, and from September $16^{\text {th }}$ to November $25^{\text {th }}$,
2013. The temperatures ranged from 13 to $26{ }^{\circ} \mathrm{C}$ and from 16 to $27{ }^{\circ} \mathrm{C}$, respectively. Plants were cultivated in $240 \mathrm{~cm}^{3}$ polypropylene tubes, containing vermiculite $\left(160 \mathrm{~cm}^{3}\right)$ and sand $\left(80 \mathrm{~cm}^{3}\right)(2: 1)$, and irrigated with nutrient solution (HOAGLAND; ARNON, 1950), according to the plants need. M. bimucronata and M. foliolosa seeds were disinfected using the same procedure applied in $M$. atropurpureum seeds, and went through breaking dormancy process for 10 minutes in pure sulfuric acid. Afterwards, they were subjected to successive washings in sterile distilled water. After presprouting seed in growth chamber $\left(28^{\circ} \mathrm{C}\right.$ for 48 hours), one plantlet was transferred to each tube. Plants were harvested after 70 days to determine plant height and diameter, number of nodules (NN), nodules dry matter production (NDM), shoot dry matter (SDM), root dry matter (RDM), and total dry matter (TDM), which was obtained by the sum of SDM and RDM. Dickson quality index (DQI) was obtained by the following equation (1):

$D Q I=[$ total dry matter $/(H D R+S R R)]$

In which: SRR is the ratio between shoot dry matter and root dry matter, and HDR is the ratio between shoot height and stem diameter (DICKSON; LEAF; HOSNER, 1960).

Data were subjected to analysis of variance

Table 1 - Identification and origin of the 14 Burkholderia strains used in authentication trials, and symbiotic efficiency in $M$. atropurpureum, M. bimucronata and M. foliolosa, (CARVALHO, 2010)

\begin{tabular}{|c|c|c|c|c|c|c|c|c|c|}
\hline \multirow{2}{*}{ Strains } & \multirow{2}{*}{ Habitat } & \multicolumn{4}{|c|}{ Cultural characteristic in medium $79^{(1)}$} & \multirow[t]{2}{*}{ NBP } & \multicolumn{3}{|c|}{ Most similar sequences found in the Genbank } \\
\hline & & GT & $\mathrm{pH}$ & Colony color & $\emptyset^{(2)}(\mathrm{mm})$ & & Species & SI (\%) & Number of accession \\
\hline \multicolumn{10}{|c|}{ Mimosa tenuiflora ${ }^{(3)}$} \\
\hline UFLA 01-726 & Cerrado & FT & alcaline & white & 2 & 519 & Burkholderia sp. & 99 & FN543721 \\
\hline UFLA 01-756 & Cerrado & FT & acid / alkaline & white & $<1$ & 901 & B. nodosa & 99 & AY773192 \\
\hline UFLA 01-733 & Cerrado & FT & alkaline & white & 1 & 678 & Burkholderia sp. & 99 & FN543723 \\
\hline UFLA 01-753 & Cerrado & FT & alkaline & colorless & 1 & 1246 & B. nodosa & 99 & AY773192 \\
\hline UFLA $01-748$ & Cerrado & FT & alkaline & white & 1 & 725 & Burkholderia sp. & 100 & FN543681 \\
\hline UFLA 01-731 & Peat bogs & FT & alkaline & white & 2 & 1272 & Burkholderia nodosa & 99 & AY773192 \\
\hline UFLA 01-744 & Peat bogs & FT & Acid & colorless & 1 & 866 & Burkholderia sp. & 100 & FN543748 \\
\hline UFLA 01-739 & Rocky outcrops & FT & Acid & yellow & 1 & 883 & Burkholderia sp. & 99 & FN543691 \\
\hline UFLA 01-751 & Rocky outcrops & FT & Acid & colorless & 1 & 879 & Burkholderia sp. & 99 & FN543677 \\
\hline UFLA 01-732 & Peat bogs & IT & acid / alkaline & white & 1 & 619 & Burkholderia sp. & 99 & FN543777 \\
\hline \multicolumn{10}{|c|}{ Macroptilium atropurpureum ${ }^{(3)}$} \\
\hline UFLA 04-248 & Cerrado & FT & alkaline & white & 1 & 710 & Burkholderia sp. & 99 & FN54379 \\
\hline UFLA 04-269 & Cerrado & FT & alkaline & white & 1 & 839 & Burkholderia sp. & 99 & EU219864 \\
\hline UFLA 04-405 & Rocky outcrops & FT & alkaline & white & 2 & 778 & Burkholderia sp. & 97 & AB366316 \\
\hline UFLA 04-260 & Sandy bogs & FT & alkaline & colorless & 1 & 800 & Burkholderia sp. & 99 & FN543722 \\
\hline
\end{tabular}

${ }^{(1)}$ GT - Growth time; FT - fast; IT - Intermediate. ${ }^{(2)}$ Colony diameter (mm). NBP - Number of Base Pairs; SI (\%) - Percentage of Similatiry in the GeneBank; ${ }^{(3)}$ Host Plant 
by using the statistical analysis program SISVAR version 5.3 (FERREIRA, 2011). The effects of the treatments were compared by the Scott-Knott test at $5 \%$ probability. NN data and NDM were transformed into square root of $\mathrm{Y}+0.5$. Graphs were obtained by the R software.

\section{RESULTS AND DISCUSSION}

UFLA 04-212 (Bradyrhizobium sp.) was able to nodulate and promote growth of $M$. atropurpureum (Figura 1), which indicates that the experimental conditions were suitable for nodulation. However, of the 14 Burkholderia strains (Table 1), only UFLA 01-726 and UFLA 04-248 (14\%) nodulated M. atropurpureum, but inefficiently, i.e., growth was similar to that of the control without inoculation. The species $M$. atropurpureum has been used as trap plant in studies on diversity since they capture bacteria of the alphaproteobacteria and betaproteobacteria classes (LIMA et al., 2009). Although the interaction between Burkholderia and $M$. atropurpureum enable the formation of nodules (ANGUS et al., 2013; ELLIOT et al., 2007; LIMA et al., 2009; MISHRA et al., 2012), this interaction is not always considered effective (ANGUS et al., 2013; BARRET; PARKER, 2005; MOULIN et al., 2001). Angus et al. (2013) reported that B. tuberum (STM 678 $)$ favored the growth of $M$. atropurpureum. However, this effect was attributed to other processes that promote plant growth, since nodules were ineffective. Furthermore, there was no comparison with a positive control for nodulation and efficiency, but with an uninoculated control and with CIAT 899 (Rhizobium tropici) strain, which was inefficient.

Of the four strains isolated from $M$. atropurpureum nodules (Table 1), only one (UFLA 04-248) nodulated while re-inoculated in this legume. This behavior was

Figure 1 - Shoot dry matter, root dry matter and total dry matter (g), with coefficient of variation (CV) of 45.3, 23.3 and 31.4\%, respectively, of Macroptilium atropurpureum, with the different treatments: treatments with individual inoculation with strains (Table 1 indicates the identification of strains); and two treatments without inoculation: one containing high mineral $\mathrm{N}$ concentration $-52.5 \mathrm{mg} \mathrm{L}^{-1}$ (With $\mathrm{N}$ ), and another containing low mineral $\mathrm{N}$ concentration- $5.25 \mathrm{mg} \mathrm{L}^{-1}$ (Minimum $\mathrm{N}$ ) concentration. All inoculated treatments received low mineral $\mathrm{N}$ concentration- $5.25 \mathrm{mg} \mathrm{L}^{-1}$. Columns followed by the same letter do not statistically differ by the Scott-Knott test at $5 \%$ probability

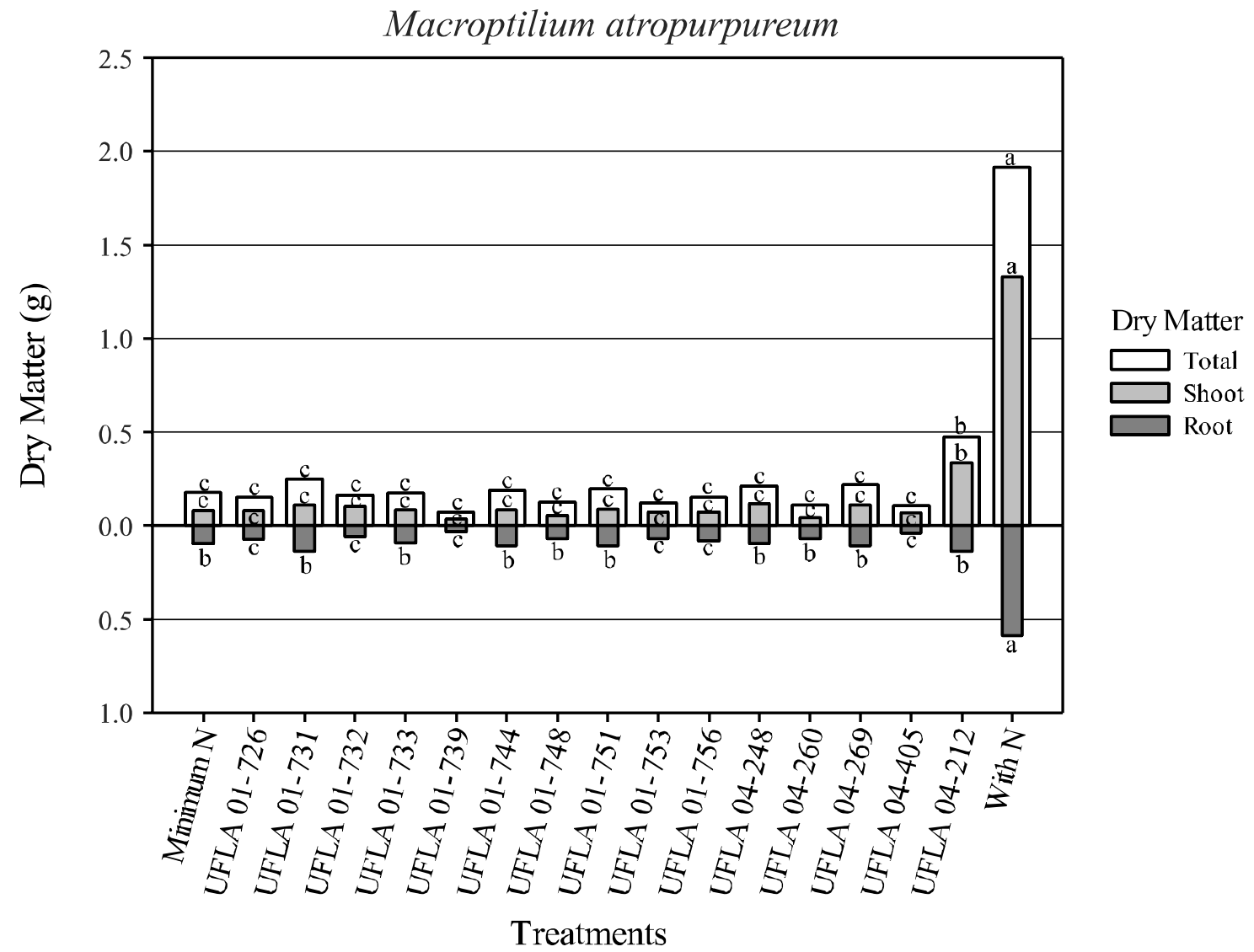


also observed by other authors, when Burkholderia fungorum strains isolated from $M$. atropurpureum did not nodulate after re-inoculation in the same species (SILVA et al., 2012). However, Burkholderia was able to nodulate common bean (FERREIRA et al., 2012).

Burkholderia strains presented higher capacity of establishing symbiosis with the plants of the genus Mimosa, since $100 \%$ of the tested strains nodulated $M$. bimucronata species, and $86 \%$ nodulated $M$. foliolosa species (Tables 2 and 3). The four strains isolated from $M$. atropurpureum nodulated $M$. bimucronata, and three nodulated $M$. foliolosa (Tables 2 and 3). The present study corroborates other researches, which show higher affinity of Burkholderia strains with Mimosa genus. This affinity was indicated by the high frequency of Burkholderia strains isolated from Mimosa spp. located in different ecosystems (BARRET; PARKER, 2005; BONTEMPS et al., 2010; CHEN et al., 2003, 2005, 2006, 2007, 2008; MISHRA et al., 2012; REIS JÚNIOR et al., 2010). However, Elliot et al. (2007) found that the strain Burkholderia tuberum STM678 ${ }^{\mathrm{T}}$ isolated from nodules of Aspalathus carnosa (MOULIN et al., 2001) failed to nodulate three species of Mimosa (Mimosa pigra, $M$. diplotricha and $M$. pudica), probably for presenting nodulation gene sequences different from those of nodulating Burkholderia species described, and which establish symbiosis with Mimosa spp. (GYANESHWAR et al., 2011).

In the experiment carried out with the species $M$. bimucronata, there was significant effects of treatments for most variables NN, NDM, SDM, plant height, diameter, and DQI (Table 2). The strains UFLA 01-732, UFLA 01733, UFLA 01-739, UFLA 01-748, UFLA 01- 751, UFLA 01-756, UFLA 04-248 and UFLA 04-405 presented higher number of nodules, and were grouped with the inoculant strain for this culture (BR 3460) (Table 2).

These strains, except for UFLA 01-756, also had higher nodules dry matter production. The strains UFLA 01-744, UFLA 01-753, UFLA 04-260, UFLA 04-269, despite not presenting number of nodules similar to that of the inoculant strain (BR 3460), presented equivalent nodules dry matter production (Table 2). In relation to shoot dry matter production, the strains UFLA 01-731, UFLA 01-739, UFLA 01-748, UFLA 04-260, UFLA 04-

Table 2 - Number of nodules (NN), nodules dry matter (NDM), shoot dry matter (SDM), root dry matter (RDM), and total dry matter (TDM), plant height and diameter in Mimosa bimucronata and Dickson quality index (DQI) in different treatments

\begin{tabular}{|c|c|c|c|c|c|c|c|c|}
\hline \multirow{2}{*}{ Treatments } & \multirow{2}{*}{ NN } & NDM & SDM & RDM & TDM & \multirow{2}{*}{ Height $\mathrm{cm}$} & \multirow{2}{*}{ Diameter mm } & \multirow{2}{*}{ DQI } \\
\hline & & \multicolumn{4}{|c|}{ 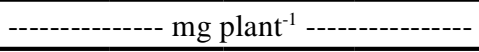 } & & & \\
\hline $5.25 \mathrm{mg} \mathrm{L}^{-1} \mathrm{~N}$ Without inoculation & $0 \mathrm{~b}$ & $0 \mathrm{~b}$ & $135 \mathrm{~b}$ & $71.3 \mathrm{a}$ & $207.5 \mathrm{a}$ & $12.67 \mathrm{~b}$ & $1.14 \mathrm{~b}$ & $0.01404 \mathrm{~b}$ \\
\hline UFLA $01-726+5.25 \mathrm{mg} \mathrm{L}^{-1} \mathrm{~N}$ & $50.75 \mathrm{~b}$ & $3.7 \mathrm{~b}$ & $140 \mathrm{~b}$ & $73.8 \mathrm{a}$ & $213.8 \mathrm{a}$ & $12.76 \mathrm{~b}$ & $1.33 \mathrm{~b}$ & $0.01939 \mathrm{~b}$ \\
\hline UFLA $01-731+5.25 \mathrm{mg} \mathrm{L}^{-1}$ de $\mathrm{N}$ & $55.62 \mathrm{~b}$ & $6.2 \mathrm{~b}$ & $256 \mathrm{a}$ & $50 \mathrm{a}$ & $303.8 \mathrm{a}$ & $18.52 \mathrm{a}$ & $1.56 \mathrm{a}$ & $0.01816 \mathrm{~b}$ \\
\hline UFLA $01-732+5.25 \mathrm{mg} \mathrm{L}^{-1} \mathrm{de} \mathrm{N}$ & $134 \mathrm{a}$ & $11.2 \mathrm{a}$ & $202 \mathrm{~b}$ & $86.3 \mathrm{a}$ & $288.8 \mathrm{a}$ & $14.92 \mathrm{a}$ & $1.44 \mathrm{a}$ & $0.02152 \mathrm{~b}$ \\
\hline UFLA $01-733+5.25 \mathrm{mg} \mathrm{L}^{-1}$ de $\mathrm{N}$ & $130.75 \mathrm{a}$ & $16.2 \mathrm{a}$ & $171 \mathrm{~b}$ & $76.3 \mathrm{a}$ & 248.8 a & $11.31 \mathrm{~b}$ & $1.14 \mathrm{~b}$ & $0.02116 \mathrm{~b}$ \\
\hline UFLA $01-739+5.25 \mathrm{mg} \mathrm{L}^{-1} \mathrm{de} \mathrm{N}$ & $138.62 \mathrm{a}$ & $15.0 \mathrm{a}$ & $224 \mathrm{a}$ & $102.5 \mathrm{a}$ & $323.8 \mathrm{a}$ & $14.95 \mathrm{a}$ & $1.64 \mathrm{a}$ & $0.02960 \mathrm{a}$ \\
\hline UFLA $01-744+5.25 \mathrm{mg} \mathrm{L}^{-1} \mathrm{de} \mathrm{N}$ & $53.62 \mathrm{~b}$ & $10.0 \mathrm{a}$ & $144 \mathrm{~b}$ & $85.0 \mathrm{a}$ & $227.5 \mathrm{a}$ & $11.5 \mathrm{~b}$ & $1.43 \mathrm{a}$ & $0.02482 \mathrm{a}$ \\
\hline UFLA $01-748+5.25 \mathrm{mg} \mathrm{L}^{-1}$ de $\mathrm{N}$ & $156.12 \mathrm{a}$ & $18.7 \mathrm{a}$ & $285 \mathrm{a}$ & $87.5 \mathrm{a}$ & $375.0 \mathrm{a}$ & 18.26 a & $1.57 \mathrm{a}$ & $0.02500 \mathrm{a}$ \\
\hline UFLA $01-751+5.25 \mathrm{mg} \mathrm{L}^{-1} \mathrm{de} \mathrm{N}$ & $119.87 \mathrm{a}$ & $10.0 \mathrm{a}$ & $206 \mathrm{~b}$ & $83.8 \mathrm{a}$ & $287.5 \mathrm{a}$ & $13.86 \mathrm{~b}$ & $1.28 \mathrm{~b}$ & $0.02011 \mathrm{~b}$ \\
\hline UFLA $01-753+5.25 \mathrm{mg} \mathrm{L}^{-1} \mathrm{de} \mathrm{N}$ & $66.37 \mathrm{~b}$ & $11.2 \mathrm{a}$ & $199 \mathrm{~b}$ & $87.5 \mathrm{a}$ & $283.8 \mathrm{a}$ & $13.21 \mathrm{~b}$ & $1.51 \mathrm{a}$ & $0.02647 \mathrm{a}$ \\
\hline UFLA $01-756+5.25 \mathrm{mg} \mathrm{L}^{-1} \mathrm{de} \mathrm{N}$ & $104.12 \mathrm{a}$ & $6.2 \mathrm{~b}$ & $194 \mathrm{~b}$ & $82.5 \mathrm{a}$ & $275.0 \mathrm{a}$ & $14.7 \mathrm{a}$ & $1.51 \mathrm{a}$ & $0.02387 \mathrm{a}$ \\
\hline UFLA $04-248+5.25 \mathrm{mg} \mathrm{L}^{-1}$ de $\mathrm{N}$ & $144 \mathrm{a}$ & $12.5 \mathrm{a}$ & $161 \mathrm{~b}$ & $80.0 \mathrm{a}$ & $240.0 \mathrm{a}$ & $12.76 \mathrm{~b}$ & $1.62 \mathrm{a}$ & $0.02618 \mathrm{a}$ \\
\hline UFLA $04-260+5.25 \mathrm{mg} \mathrm{L}^{-1}$ de N & $31.75 \mathrm{~b}$ & $11.2 \mathrm{a}$ & 242 a & $97.5 \mathrm{a}$ & $340.0 \mathrm{a}$ & $15.11 \mathrm{a}$ & $1.55 \mathrm{a}$ & $0.02675 \mathrm{a}$ \\
\hline UFLA $04-269+5.25 \mathrm{mg} \mathrm{L}^{-1} \mathrm{de} \mathrm{N}$ & $35.12 \mathrm{~b}$ & $10.0 \mathrm{a}$ & $186 \mathrm{~b}$ & $78.8 \mathrm{a}$ & $265.0 \mathrm{a}$ & $12.78 \mathrm{~b}$ & $1.34 \mathrm{~b}$ & $0.02467 \mathrm{a}$ \\
\hline UFLA $04-405+5.25 \mathrm{mg} \mathrm{L}^{-1}$ de N & $123.87 \mathrm{a}$ & $21.2 \mathrm{a}$ & $265 \mathrm{a}$ & $118.8 \mathrm{a}$ & $383.8 \mathrm{a}$ & $16.48 \mathrm{a}$ & $1.69 \mathrm{a}$ & $0.03110 \mathrm{a}$ \\
\hline BR-3460 +5.25 mg L-1 de N & $89.75 \mathrm{a}$ & $13.7 \mathrm{a}$ & $207 \mathrm{~b}$ & $100.0 \mathrm{a}$ & 306.3 a & $17.07 \mathrm{a}$ & $1.55 \mathrm{a}$ & $0.02387 \mathrm{a}$ \\
\hline $52.5 \mathrm{mg} \mathrm{L}^{-1}$ de $\mathrm{N}$ Without inoculation & $0 \mathrm{~b}$ & $0 \mathrm{~b}$ & $295 \mathrm{a}$ & $117.5 \mathrm{a}$ & $412.5 \mathrm{a}$ & $13.17 \mathrm{~b}$ & $1.58 \mathrm{a}$ & $0.02549 \mathrm{a}$ \\
\hline $\mathrm{CV}(\%)$ & 46.41 & 67.50 & 43.16 & 48.84 & 43.26 & 26.52 & 16.64 & 15.95 \\
\hline
\end{tabular}

Table 1 shows the identification of strains that compose treatments with inoculation, and BR 3460 is the positive control. The two treatments without inoculation: one containing high mineral $\mathrm{N}$ concentration $\left(52.5 \mathrm{mg} \mathrm{L}^{-1}\right)$ and another containing low mineral $\mathrm{N}$ concentration $\left(5.25 \mathrm{mg} \mathrm{L}^{-1}\right)$ are the negative controls. Columns followed by the same letter do not present statistical differences by the Scott-Knott test, at 5\% probability 
405 were superior to the inoculant strain, and equivalent to the control with high mineral $\mathrm{N}$ concentration (Table 2). There were no differences between treatments in relation to root dry matter and total dry matter (Table 2).

In relation to the height of $M$. bimucronata, the strains UFLA 01-731, UFLA 01-732, UFLA 01-739, UFLA 01-748, UFLA 01-756, UFLA 04-260, UFLA 0440 were similar to the strain BR 3460, which were superior to the control with high nitrogen concentration (Table 2). All these strains plus UFLA 01-744, UFLA 01-753, and UFLA 04-248 also promoted higher diameter growth, and were equivalent to the control with high mineral $\mathrm{N}$ concentration.

For the Dickson quality index (DQI), the strains UFLA 01-739, UFLA 01-744, UFLA 01-748, UFLA 01-753, UFLA 01-756, UFLA 04-248, UFLA 04-260, UFLA 04-269 and UFLA 04-405 were equivalent to the inoculant strain (BR 3460) and to the control with high $\mathrm{N}$ concentration (Table 2). However, the strains UFLA 01-739, UFLA 01-748 and UFLA 04-405 should be highlighted. Of the 14 tested strains, in the experiment carried out with $M$. foliolosa, only two did not nodulate this species, UFLA 01-731 and UFLA 04-269, which were isolated from Mimosa tenuiflora and Macroptilium atropurpureum, respectively (Table 3). M. folilosa is an endemic species of rupestrian grassland of Serra do Cipo, MG, and this is the first study that evaluates the nodulation and efficiency of nitrogen-fixing strains in its development; therefore, no strains have been approved by MAPA as inoculant yet.

The strains that presented higher number of nodules production were UFLA 01-726, UFLA 01-733, UFLA 01-748 and UFLA 04-248. With the exception of UFLA $01-733$, these strains also promoted greater nodules dry matter production (Table 3 ).

All parameters showed significant effects; however, no strain was able to surpass, nor was equivalent to the results obtained with the control with high nitrogen concentration for shoot dry matter, total dry matter, height and diameter (Table 3). Root dry matter production by the strains UFLA 01-731, UFLA 01-733, UFLA 01-751, UFLA 04-260 and UFLA 04-269 was equivalent to that of the control with high mineral $\mathrm{N}$ concentration.

The values obtained by the Dickson quality index

Table 3 - Number of nodules (NN), nodules dry matter (NDM), shoot dry matter (SDM), root dry matter (RDM), and total dry matter(TDM), height and diameter of Mimosa foliolosa and Dickson quality index (DQI), in different treatments

\begin{tabular}{|c|c|c|c|c|c|c|c|c|}
\hline \multirow{2}{*}{ Treatments } & \multirow{2}{*}{ NN } & NDM & SDM & RDM & TDM & Height $\mathrm{cm}$ & \multirow{2}{*}{ Diameter mm } & \multirow{2}{*}{ DQI } \\
\hline & & \multicolumn{5}{|c|}{ 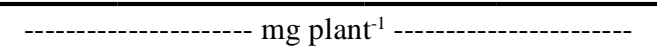 } & & \\
\hline $5.25 \mathrm{mg} \mathrm{L}^{-1}$ de N Without inoculation & $0 \mathrm{~d}$ & $0 \mathrm{c}$ & $207.2 \mathrm{~b}$ & $37.70 \mathrm{~b}$ & $245.0 \mathrm{~b}$ & $10.15 \mathrm{~b}$ & $1.4317 \mathrm{~b}$ & $0.01952 \mathrm{~b}$ \\
\hline UFLA $01-726+5.25 \mathrm{mg} \mathrm{L}^{-1} \mathrm{de} \mathrm{N}$ & $24.75 \mathrm{a}$ & $26.7 \mathrm{a}$ & $245.1 \mathrm{~b}$ & $48.70 \mathrm{~b}$ & $293.9 \mathrm{~b}$ & $10.99 \mathrm{~b}$ & $1.5462 \mathrm{~b}$ & $0.02593 \mathrm{a}$ \\
\hline UFLA $01-731+5.25 \mathrm{mg} \mathrm{L}^{-1} \mathrm{de} \mathrm{N}$ & $0 \mathrm{~d}$ & $0 \mathrm{c}$ & $164.4 \mathrm{c}$ & $31.37 \mathrm{a}$ & $195.7 \mathrm{c}$ & $10.14 \mathrm{~b}$ & $1.0762 \mathrm{c}$ & $0.01260 \mathrm{~b}$ \\
\hline UFLA $01-732+5.25 \mathrm{mg} \mathrm{L}^{-1}$ de $\mathrm{N}$ & $16.37 \mathrm{~b}$ & $10.2 \mathrm{c}$ & $132.2 \mathrm{c}$ & $30.50 \mathrm{~b}$ & $161.6 \mathrm{c}$ & $7.74 \mathrm{c}$ & $1.1987 \mathrm{c}$ & $0.01586 \mathrm{~b}$ \\
\hline UFLA $01-733+5.25 \mathrm{mg} \mathrm{L}^{-1} \mathrm{de} \mathrm{N}$ & $28.00 \mathrm{a}$ & $14.7 \mathrm{~b}$ & $137.7 \mathrm{c}$ & $29.62 \mathrm{a}$ & $167.4 \mathrm{c}$ & $7.20 \mathrm{c}$ & $1.1925 \mathrm{c}$ & $0.01500 \mathrm{~b}$ \\
\hline UFLA $01-739+5.25 \mathrm{mg} \mathrm{L}^{-1} \mathrm{de} \mathrm{N}$ & $12.12 \mathrm{c}$ & $19.2 \mathrm{~b}$ & $197.9 \mathrm{~b}$ & $45.50 \mathrm{~b}$ & $243.4 \mathrm{~b}$ & $9.43 \mathrm{~b}$ & $1.4637 \mathrm{~b}$ & $0.01723 \mathrm{a}$ \\
\hline UFLA $01-744+5.25 \mathrm{mg} \mathrm{L}^{-1} \mathrm{de} \mathrm{N}$ & $3.62 \mathrm{~d}$ & $4.4 \mathrm{c}$ & $166.2 \mathrm{c}$ & $30.37 \mathrm{~b}$ & $196.6 \mathrm{c}$ & $9.25 \mathrm{~b}$ & $1.1825 \mathrm{c}$ & $0.01330 \mathrm{~b}$ \\
\hline UFLA $01-748+5.25 \mathrm{mg} \mathrm{L}^{-1} \mathrm{de} \mathrm{N}$ & $26.50 \mathrm{a}$ & $30.4 \mathrm{a}$ & $276.1 \mathrm{~b}$ & $55.62 \mathrm{~b}$ & $331.7 \mathrm{~b}$ & $11.65 \mathrm{~b}$ & $1.6037 \mathrm{~b}$ & $0.02823 \mathrm{a}$ \\
\hline UFLA $01-751+5.25 \mathrm{mg} \mathrm{L}^{-1} \mathrm{de} \mathrm{N}$ & $6.38 \mathrm{c}$ & $7.7 \mathrm{c}$ & $209.5 \mathrm{~b}$ & $40.50 \mathrm{a}$ & $253.0 \mathrm{~b}$ & $10.00 \mathrm{~b}$ & $1.6012 \mathrm{~b}$ & $0.02249 \mathrm{a}$ \\
\hline UFLA $01-753+5.25 \mathrm{mg} \mathrm{L}^{-1}$ de $\mathrm{N}$ & $1.43 \mathrm{~d}$ & $5.2 \mathrm{c}$ & $166.0 \mathrm{c}$ & $27.75 \mathrm{~b}$ & $193.7 \mathrm{c}$ & $8.77 \mathrm{c}$ & $1.2857 \mathrm{c}$ & $0.01561 \mathrm{~b}$ \\
\hline UFLA $01-756+5.25 \mathrm{mg} \mathrm{L}^{-1} \mathrm{de} \mathrm{N}$ & $6.00 \mathrm{c}$ & $5.1 \mathrm{c}$ & $201.1 \mathrm{~b}$ & $35.75 \mathrm{~b}$ & $236.9 \mathrm{~b}$ & $9.69 \mathrm{~b}$ & $1.4986 \mathrm{~b}$ & $0.01723 \mathrm{~b}$ \\
\hline UFLA $04-248+5.25 \mathrm{mg} \mathrm{L}^{-1} \mathrm{de} \mathrm{N}$ & $29.00 \mathrm{a}$ & $28.0 \mathrm{a}$ & $196.6 \mathrm{~b}$ & $46.25 \mathrm{~b}$ & $242.9 \mathrm{~b}$ & $9.73 \mathrm{~b}$ & $1.2342 \mathrm{c}$ & $0.02164 \mathrm{a}$ \\
\hline UFLA $04-260+5.25 \mathrm{mg} \mathrm{L}^{-1} \mathrm{de} \mathrm{N}$ & $3.12 \mathrm{c}$ & $9.1 \mathrm{c}$ & $166.2 \mathrm{c}$ & $36.87 \mathrm{a}$ & $255.9 \mathrm{~b}$ & $8.51 \mathrm{c}$ & $1.4662 \mathrm{~b}$ & $0.02365 \mathrm{a}$ \\
\hline UFLA $04-269+5.25 \mathrm{mg} \mathrm{L}^{-1} \mathrm{de} \mathrm{N}$ & $0 \mathrm{~d}$ & $0 \mathrm{c}$ & $140.9 \mathrm{c}$ & $32.25 \mathrm{a}$ & $173.1 \mathrm{c}$ & $9.00 \mathrm{c}$ & $1.0400 \mathrm{c}$ & $0.01195 \mathrm{~b}$ \\
\hline UFLA $04-405+5.25 \mathrm{mg} \mathrm{L}^{-1}$ de $\mathrm{N}$ & $12.87 \mathrm{c}$ & $11.1 \mathrm{c}$ & $184.0 \mathrm{~b}$ & $38.12 \mathrm{~b}$ & $250.7 \mathrm{~b}$ & $9.46 \mathrm{~b}$ & $1.3450 \mathrm{c}$ & $0.01913 \mathrm{a}$ \\
\hline UFLA $01-750+5.25 \mathrm{mg} \mathrm{L}^{-1} \mathrm{de} \mathrm{N}$ & $21.12 \mathrm{~b}$ & $21.9 \mathrm{~b}$ & $194.9 \mathrm{~b}$ & $52.50 \mathrm{~b}$ & $247.4 \mathrm{~b}$ & $9.24 \mathrm{~b}$ & $1.4937 \mathrm{~b}$ & $0.02668 \mathrm{a}$ \\
\hline $52.5 \mathrm{mg} \mathrm{L}^{-1}$ de N Without inoculation & $0 \mathrm{~d}$ & $0 \mathrm{c}$ & $429.1 \mathrm{a}$ & $68.62 \mathrm{a}$ & 497.7 a & $16.55 \mathrm{a}$ & $2.0650 \mathrm{a}$ & $0.03462 \mathrm{a}$ \\
\hline $\mathrm{CV}(\%)$ & 62.36 & 71.64 & 35.03 & 46.57 & 33.97 & 21.27 & 27.44 & 23.25 \\
\hline
\end{tabular}

Table 1 shows the identification of strains that compose the inoculation treatments, and UFLA 01-750 is the positive control. The two treatments without inoculation: one containing high mineral $\mathrm{N}$ concentration $\left(52.5 \mathrm{mg} \mathrm{L}^{-1}\right)$, and another containing low mineral $\mathrm{N}$ concentration $\left(5.25 \mathrm{mg} \mathrm{L}^{-1}\right)$ are the negative controls. Columns followed by the same letter do not present statistical differences by the Scott-Knott test, at 5\% probability 
by the strains UFLA 01-726, UFLA 01-739, UFLA 01748, UFLA 01-750, UFLA 01-751, UFLA 04-248, UFLA 04-260, and UFLA 04-405 were equivalent to that of the control with high $\mathrm{N}$ concentration (Table 3 ).

The Mimosa species evaluated this study are promising to be used in the recovery of degraded areas. The use of native legumes species that establish symbosis with nitrogen-fixing bacteria is of great interest for degraded areas restoration, since they established themselves in the field more quickly, and promote greater biomass accumulation and contribute to the improvement of soil fertility, favoring other species that are not able to establish this type of symbiosis (CHAER et al., 2011).

This study is the first to evaluate the potential of bacteria strains from nodules of legume species cultivated in rupestrian grasslands soils. The soils of this region are oligotrophic and acid (CARVALHO et al., 2012; 2014; NEGREIROS; MORAIS; FERNANDES, 2008), and the selection of strains adapted to these conditions may be used to obtain seedlings for the recovery of areas which have soils with these characteristics.

Although Mimosa foliolosa is an endemic species of the same region where the Burkholderia strains were obtained, they were more efficient in Mimosa bimucronata.

It can be considered that the strains UFLA 01-739, 01-748, 01-751, 04-260, 04-405 were in general the most effective in promoting the growth of Mimosa species. UFLA 01-739, 01-748, and 04-405 were considered potential inculants for $M$. bimucronata; and UFLA 01-751 and UFLA 04-260 were considered potential inoculants for M. foliolosa.

\section{CONCLUSIONS}

1. Burkholderia strains establish symbiosis with the species Macroptilium atropurpureum, Mimosa bimucronata and Mimosa foliolosa, and present greater specificity for species of the genus Mimosa;

2. Macroptilium atropurpureum nodulation by Burkholderia strains occurred only with two of the 14 strains, and was inefficient;

3. Burkholderia strains isolated from Macroptilium atropurpureum and Mimosa tenuiflora cultivated in rupestrian grasslands soils promote plant growth of the species Mimosa bimucronata and Mimosa foliolosa, with potential to be used as inoculants for these species.
4. Burkholderia strains promote Mimosa spp. growth, but not Macroptilium atropurpureum.

\section{ACKNOWLEDGEMENTS} To the National Council for
Scientific and Technological Development
$(\mathrm{CNPq})$ and to the Coordination for the Improvement of Higher Education Personnel (CAPES) for the finantial support to this research project, and for the study and research scholarships.

\section{REFERENCES}

ANGUS, A. A. et al. Nodulation and effective nitrogen fixation of Macroptilium atropurpureum (siratro) by Burkholderia tuberum, a nodulating and plant growth promoting beta-proteobacterium, are influenced by environmental factors. Plant and Soil, v. 369, n. 1, p. 543-562, 2013.

BARRET, C. F.; PARKER, M. A. Coexixtence of Burkholderia, Cupriavidus and Rhizobium sp. nodule bacteria on two Minosa spp. in Costa Rica. Applied and Environmental Microbiology, v. 72, n. 2, p. 1198-12016, 2006.

BARRET, C. F.; PARKER, M. A. Prevalence of Burkholderia sp. nodule symbionts on four mimosoid legumes from Barro Colorado Island, Panama. Systematic and Applied Microbiology, v. 28, n. 1, p. 57-65, 2005.

BONTEMPS, C. et al. Burkholderia species are ancient symbionts of legumes. Molecular Ecology, v. 19, n. 1, p. 44-52, 2010.

CARVAlho, F. Abundância de espécies de plantas e diversidade de simbiontes radiculares em campos rupestres da serra do cipó, MG. Tese (Doutorado em Ecologia, Conservação e Manejo da Vida Silvestre) - Instituto de Ciências Biológicas, Universidade Federal de Minas Gerais, Belo Horizonte, 2010.

CARVALHO, F. et al. Relationship between physical and chemical soil attributes and plant species diversity in tropical mountain ecosystems from Brazil. Journal of Mountain Science, v. 11, n. 4, p. 875-883, 2014.

CARVALHO, F. et al. The mosaico $\mathrm{f}$ habitats in the high-altitude brazilian rupestrian fields is a hotspot for arbuscular mycorrhizal fungi. Applied Soil Ecology, v. 52, n. 1, p. 9-19, 2012.

CHAER, G. M. et al. Nitrogen-fixing legume tree species for the reclamation of severely degraded lands in Brasil. Tree Physiology, v. 31, p. 139-149, 2011.

CHEN, W. M. et al. Burkholderia nodosa sp. nov., isolated from root nodules of the woody Brazilian legumes Mimosa bimucronata and Mimosa scabrella. International Journal of Systematic and Evolutionary Microbiology, v. 57, n. 5, p. 1055-1059, 2007. 
CHEN, W. M. et al. Burkholderia sabiae sp. nov., isolated from root nodules of Mimosa caesalpiniifolia. International Journal of Systematic and Evolutionary Microbiology, v. 58, n. 9 , p. $2174-2179,2008$.

CHEN, W. M. et al. Legume symbiotic nitrogen fixation by betaproteobacteria is widespread in nature. Journal of Bacteriology, v. 185, n. 24 , p. $7266-7272,2003$.

CHEN, W. M. et al. Proof that Burkholderia forms effective symbioses with legumes: a study of novel Mimosa-nodulating strains from South America. Applied and Environmental Microbiology, v. 71, n. 11, p. 7461-7471, 2005.

CHEN, W.-M. et al. Burkholderia mimosarum sp. nov., isolated from root nodules of Mimosa spp. From Taiwan and South America. International Journal of Systematic and Evolutionary Microbiology, v. 56, n. 8, p. 1847-1851, 2006.

COENYE, T.; VANDAMME, P. Diversity and significance of Burkholderia species occupying diverse ecological niches. Environmental Microbiology, v. 5, n. 9, p. 719-729, 2003.

DICKSON, A.; LEAF, A. L.; HOSNER, J. F. Quality appraisal of white spruce and white pine seedling stock in nurseries. Forest Chronicle, v. 36, n. 1, p. 10-13, 1960.

ELliOTT, G. N. et al. Nodulation of Cyclopia spp. (Leguminosae, Papilionoideae) by Burkholderia tuberum. Annals of Botany, v. 100, n. 7, p. 1403-1411, 2007.

FARIA, S. M. et al. Obtenção de estirpes de rizóbio eficientes na fixação biológica de nitrogênio para espécies florestais. Seropédica: Embrapa Agrobiologia, 1997. p. 1-4. (Recomendação Técnica, 3).

FERREIRA, D. F. Sisvar: a computer statistical analysis system. Ciência e Agrotecnologia, v. 35, n. 6, p. 1039-1042, 2011.

FERREIRA, P. A. A. et al. Efficient nitrogen-fixing Rhizobium strains isolated from amazonian soils are highly tolerant to acidity and aluminium. World Journal of Microbiology and Biotechnology, v. 28, n. 5, p. 1947-1959, 2012.

FLORENTINO, L. A. et al. Sesbania virgata stimulates the occurrence of its microsymbiont in soils but does not innibit microsymbiont of other species. Scentia Agricola, v. 66, n. 5, p. 667-676, 2009.
FRED, E. B.; WAKSMAN, S. A. Laboratory manual of general microbiology. New York: McGraw-Hill Book, 1928. $143 \mathrm{p}$.

GYANESHWAR, P. et al. Legume-nodulating betaproteobacteria: diversity, host range, and future prospects. The American Phytopathological Society, v. 24, n. 11, p. 1276-1288, 2011.

HOAGLAND, D. A.; ARNON, D. D. The water-culture method for growing plants without soil. Berkeley: California Agricultural of Experiment Station, 1950. 32 p. (Circular 347).

REIS JÚNIOR, F. B. dos et al. Nodulation and nitrogen fixation by Mimosa spp in the Cerrado and Caatinga biomes of Brazil. New Phytologist, v. 186, n. 4, p. 934-946, 2010.

LIMA, A. S. et al. Nitrogen-fixing bacteria communities occurring in soils under different uses in the Western Amazon Region as indicated by nodulation of siratro (Macroptilium atropurpureum). Plant and Soil, v. 319, n. 1, p. 127-145, 2009.

MISHRA, R. P. N. et al. Genetic diversity of Mimosa pudica rhizobial symbionts in soils of French Guiana: investigating the origin and diversity of Burkholderia phymatum and other betarhizobia. Microbiology Ecology, v. 79, n. 2, p. 487-503, 2012.

MOULIN, L. et al. Nodulation of legumes by members of the b-subclass of Proteobacteria. Nature, v. 411, n. 6840, p. 948-950, 2001.

NEGREIROS, D.; MORAIS, M. L. B.; FERNANDES, G. W. Caracterização da fertilidade dos solos de quatro leguminosas de campos rupestres, serra do cipó, MG, Brasil. Revista de la Ciência del Suelo y Nutrición Vegetal, v. 8, n. 3, p. 30-39, 2008.

SILVA, K. et al. Diazotrophic Burkholdria species isolated from the Amazon region exhibit phenotypical, functional andd genetic diversity. Systematic and Apllied Microbiology, v. 35 , n. 4 , p. $253-262,2012$

SOARES, B. L. et al. Cowpea symbiotic efficiency, $\mathrm{pH}$ and aluminum tolereance in nitrogen-fixing bactéria. Scientia Agricola, v. 71, n. 3, p. 171-180, 2014.

TALBI, C. et al. Burkholderia phymatum strains capable of nodulating Phaseolus vulgaris are present in Moroccan soils. Applied and Environmental Microbiology, v. 76, n. 13, p. 45874591, 2010. 